\title{
Carcinoma ex pleomorphic adenoma: a case report and review of literature
}

\author{
Deepak Khanna ${ }^{1}$, Tanay Chaubal $^{2}$, Ranjeet Bapat ${ }^{2}$, Anshad Mohamed Abdulla ${ }^{3}$, \\ Sunil Thomas Philip ${ }^{4}$, Suraj Arora ${ }^{5}$
}

1. Department of Head, neck and oncology, D.Y.Patil University School of medicine, Nerul, Navi Mumbai, Maharashtra state, India, Zip code - 400706.

2. Division of Clinical Dentistry, School of Dentistry, International Medical University, Kuala Lumpur, Malaysia, Zip code -57000 .

3. Department of Pediatric dentistry and Orthodontic Sciences, King Khalid University, Abha, Kingdom of Saudi Arabia, Pincode- 61471.

4. Department of Pedodontics and Preventive Dentistry, Noorul Islam College of Dental Sciences, Trivandrum, Kerala, India

5. Department of Restorative Dentistry, King Khalid University, Abha, Kingdom of Saudi Arabia, Pincode- 61471.

\section{E-mails:}

Deepak Khanna - dkmaxfax@gmail.com; Tanay Chaubal - tanayvc@gmail.com; Ranjeet Bapat ranjeetbapat@gmail.com; Anshad Mohamed Abdulla- anshad2004@gmail.com; Sunil Thomas Philiprubysunildr@rediffmail.com; Suraj Arora- surajarorasgrd@yahoo.co.in

\begin{abstract}
:
Background: Carcinoma ex pleomorphic adenoma (CA-ex-PA) is extremely unusual in minor salivary glands of oral cavity. CAex-PA is a carcinomatous change as a primary or as a recurrence of pleomorphic adenoma.

Objective: Due to resemblance of clinical symptoms of Ca ex PA and benign pleomorphic adenoma, it is mandatory for surgeons to keep high degree of clinical alertness, considering the peculiarity of this tumor.

Case Report: 54-year-old male presented with swelling on left side in the pre-auricular region from the middle of zygomatic arch to mastoid process and from tragus of the ear up to angle of mandible. Fine needle aspiration cytology revealed a mixture of benign and malignant components. Total left parotidectomy with left radical neck dissection followed by reconstruction with cervicodeltopectoral flap was performed. Combination of chemotherapy and radiotherapy were given to patient. Histologic examination and pre-operative fine needle aspiration cytology confirmed the diagnosis of Carcinoma ex pleomorphic adenoma (CA-ex-PA). Two-year follow-up of patient showed no recurrence of the lesion.

Conclusion: Due to the similarity in the clinical symptoms of CA-ex-PA and benign pleomorphic adenoma, it is vital that clinicians maintain a high degree of clinical vigilance, considering the oddity of this malignancy.

Keywords: Carcinoma ex pleomorphic adenoma, Fine needle aspiration cytology, parotidectomy.

DOI: https://dx.doi.org/10.4314/ahs.v19i4.50

Cite as: Khanna D, Chaubal T, Bapat R, Abdulla AM, Philip ST, Arora S. Carcinoma ex pleomorphic adenoma: a case report and review of literature. Afri Health Sci.2019;19(4):3253-3263. https:// dx.doi.org/10.4314/abs.v19i4.50
\end{abstract}

\section{Corresponding author:}

Anshad Mohamed Abdulla,

Department of Pediatric dentistry

and Orthodontic Sciences,

King Khalid University, Abha,

Aseer region,Kingdom of Saudi Arabia,

P.O Box- 61471.

Phone-+966537820023

Email: anshad2004@gmail.com

\section{Introduction}

Malignancies of parotid gland are relatively rare and account for 1-3 \% of all tumors of head. ${ }^{1}$ The most common benign salivary gland tumour is Pleomorphic adenoma (PA). It is mostly found in parotid glands and is usually managed successfully by surgical resection. ${ }^{2}$ Unfortunately around $6 \%$ of these tumours transform into Carcinoma ex pleomorphic adenoma. (Ca-ex-PA). ${ }^{2,3}$ Ca-ex-PA is defined as a carcinoma originating from a primary (de novo) or recurrent benign pleomorphic ade-

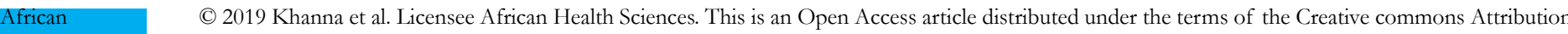

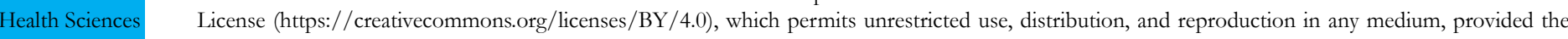
original work is properly cited.
} 
noma. ${ }^{4}$ Its incidence is about 5 to $25 \%$ of parotid carcinomas. ${ }^{5}$ The exact pathogenesis of Ca-ex-PA is not clear. One school of thought is that they are malignant from the onset whereas some believe it to be a carcinomatous transformation of a mixed tumor. ${ }^{6}$ Histopathological examinations is important aid diagnosis. The objective in presenting this particular case is to present pathological and clinical features of Ca-ex-PA.

\section{Case report}

A 54-year-old male patient reported to our institution with a swelling on left side of the pre-auricular region extending anteroposteriorly from midpart of zygomatic arch to mastoid process and superoinferiorly from tragus of the ear to the angle of mandible (Figure 1).

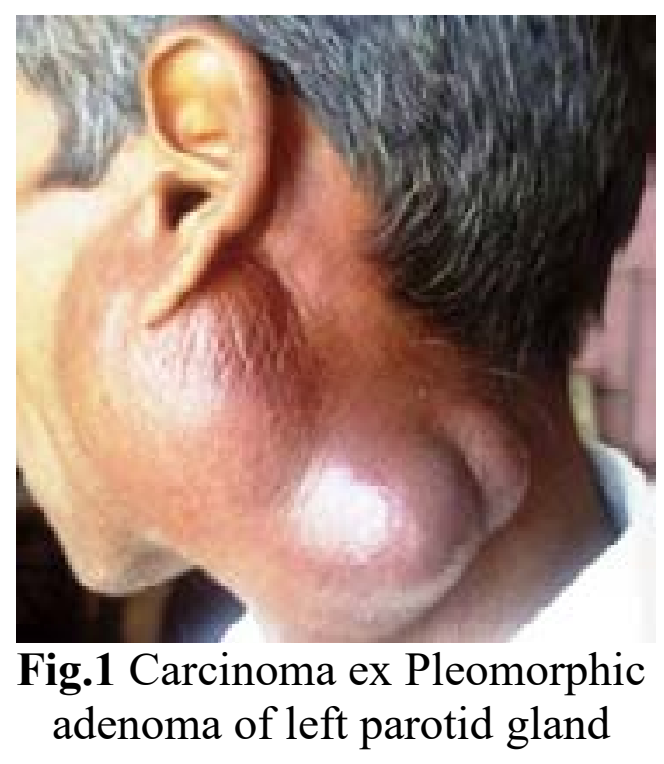

The patient also had enlarged level IIB lymph nodes. The skin over the swelling was fixed; on palpation, the lesion was hard and firm in consistency. Intra-orally, the uvula and tonsil were shifted towards the right side. Fine needle aspiration cytology showed combination of cells having benign and malignant elements (Figure 2); benign epithelial component appeared as small to round cells with bland oval nuclei while malignant component appeared as large cells with large pleomorphic nuclei showing granu- lar chromatin and high nucleus: cytoplasmic ratio (Figure 3).

Fluorodeoxyglucose (FDG) positron emission tomography depicted a high uptake in the left parotid region and in the neck nodes at level IIB, III and IV. Ultrasonography of neck was done for mapping of nodes which showed metastatic disease at level IIB and III. Treatment decision taken in our case was total parotidectomy of the left side with left radical neck dissection followed by cervicodeltopectoral flap (Figure 4). 


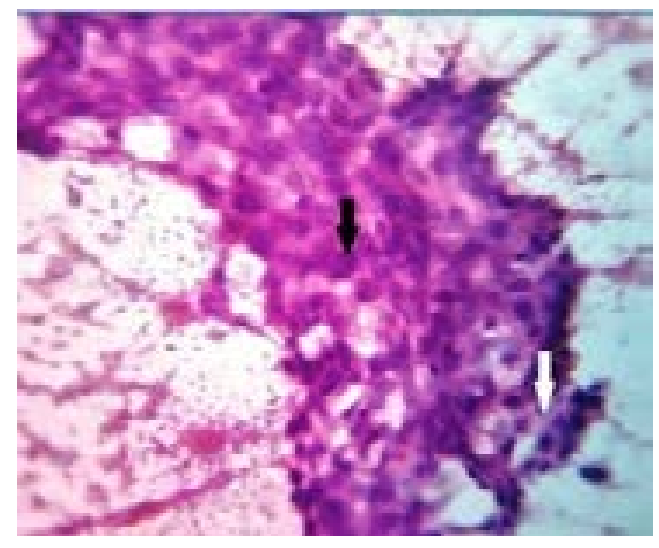

Fig.2 FNAC showing cellular smear with clusters of benign (white arrow) and malignant cells (black arrow) -PAP stain $10 \mathrm{X}$

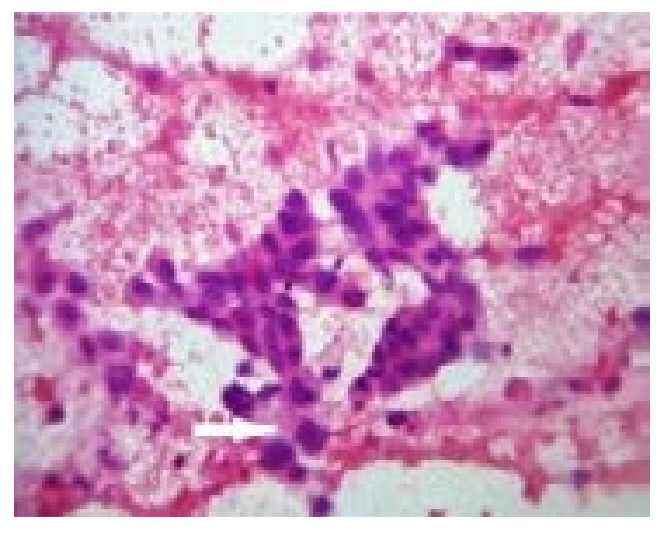

Fig. 3 FNAC showing large cells with large pleomorphic nuclei having coarse chromatin- PAP stain $-40 \mathrm{X}$ (white arrow)

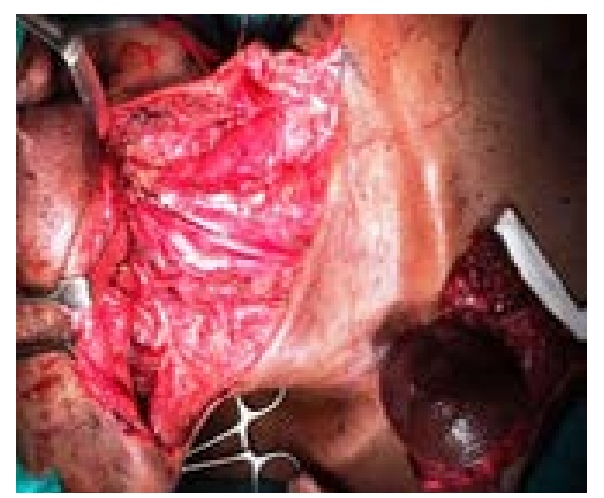

Fig.4 Intraoperative view of Parotidectomy and radical neck surgery

Most crucial part of management was resectibility of the lymph nodes as they were totally fixed on vital structures like common carotid artery and for that particular reason radical neck dissection was carried out first. Fixed skin over the lymph node was marked separately and upper African Health Sciences Vol 19 Issue 4, December, 2019 cervical incision was joined to the marked skin. Second incision was a vertical incision which was dropped from primary incision at 90 degrees to $1-1.5 \mathrm{~cm}$ above clavicle sub-platsymal flaps were raised till identification of greater auricular nerve. Clearance was done from level IA to 
IB till level V, nodes at level IIB were completely fixed to the carotid sheath however a plane could be formed over the carotid sheath to remove the nodes, Level IIB nodes were excised in total with overlying skin. XI nerve, SCM was sacrificed. Once radical neck dissection was finished primary tumor was approached with a lazy $S$ pre-auricular (Blair's incision), flap was raised in subplatsymal plane anteriorly till anterior border of paroitd gland. Dissection was deepened in pre-auricular tragus region for identification of facial nerve main trunk which could not be found so dissection was continued till the styloid process posteriorly, medially tumor was free from posterior border of ramus of mandible so it was not sacrificed however of the deep portion of gland and base of skull were blunt dissection was done with a gloved finger. External carotid artery was ligated at deeper level to medial surface of deep lobe of parotid gland and whole tumor was removed in toto. Cervicodeltopectoral flap marking was done by extending lower vertical incision till tip of acromion process of scapula continuing inferomedially towards xiphisternum medial to nipple of chest.

Haemostasis was achieved and no.16 drains were placed and suturing done in layers patient healed uneventfully, drains removed after 12 days. Patient was sent for adjuvant radiotherapy and chemotherapy with a boost of radiation at level IIB. Histopathology of the resected tumor revealed undifferentiated carcinoma ex pleomorphic adenoma suggested by pleomorphic tumor cells with focally vacuolated cytoplasm seen infiltrating into the benign pleomorphic adenoma. Foci showing infiltrating carcinoma composed of cells arranged in nests, sheets, cords and vague glandular pattern noted (Figure 5). Histopathological examination showed areas of pleomorphic adenoma composed of biphasic population of cells in chondromyxoid matrix. Duct like structures lined by inner epithelial and outer myoepithelial cells (Figure 6).

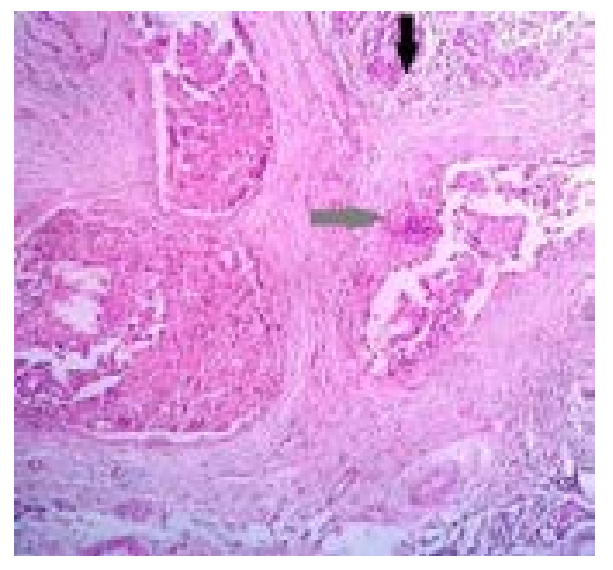

Fig.5 Areas of pleomorphic adenoma (Black arrow) with infiltrating foci of carcinoma (grey arrow) - H\&E stain-10 X

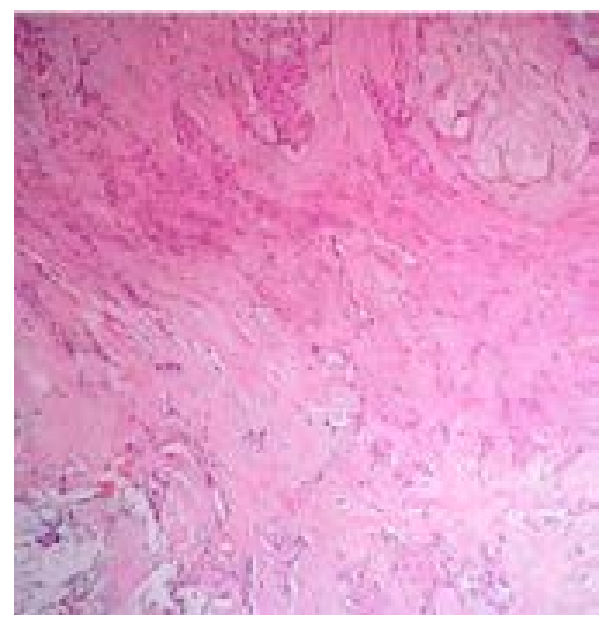

Fig 6: Pleomorphic adenoma composed of biphasic population of cells in chondromyxoid matrix-H\&E stain-10 X 
The cells are highly pleomorphic with moderate amount of eosinophilic cytoplasm, round nuclei with irregular nuclear borders, coarsely clumped chromatin with some showing prominent nucleoli (Figure 7). Post-operative immunohistochemistry and fluorescence in situ hybridization for HMGA-2 gene was positive (Figure 8). Recall after 24 months showed the absence of any recurrence (Figure 9). The overall picture was suggestive of Carcinoma ex pleomorphic adenoma (CA-ex-PA).

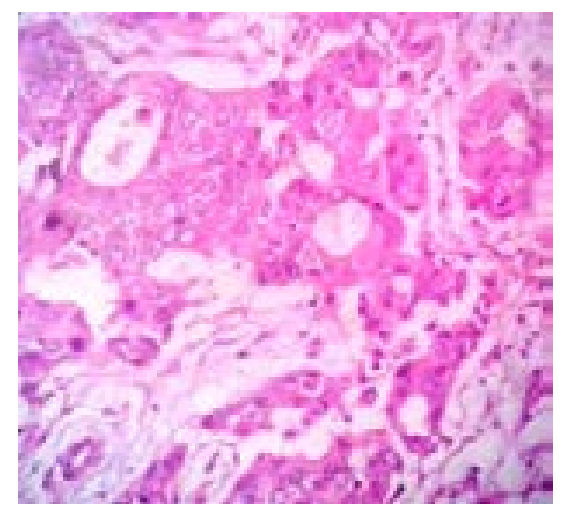

Fig 7: Foci of carcinoma composed of pleomorphic cells arranged in nests and vague glandular pattern- H \& E stain- $40 \mathrm{X}$

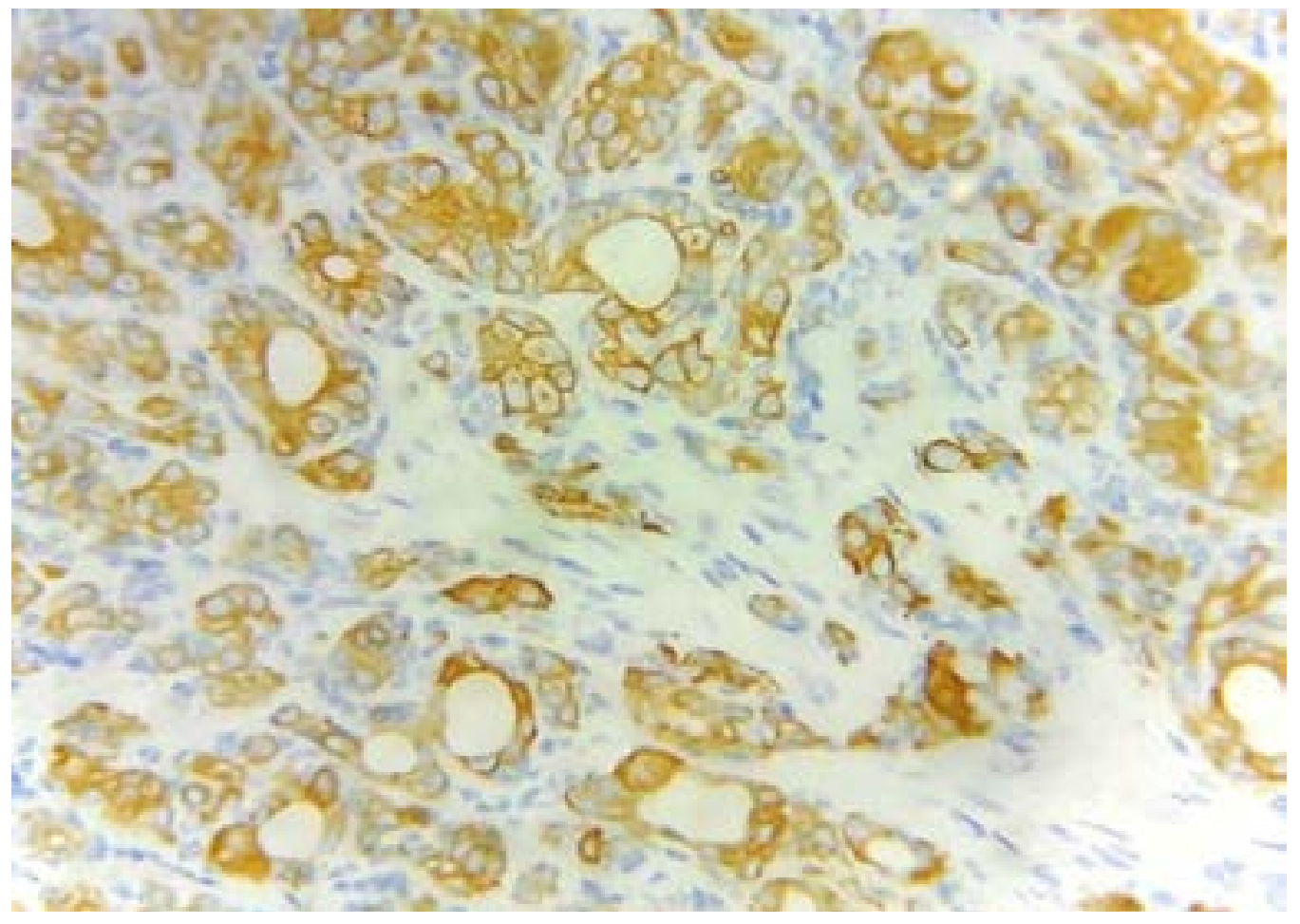

Fig. 8: Immunostain for HMGA-2 gene 


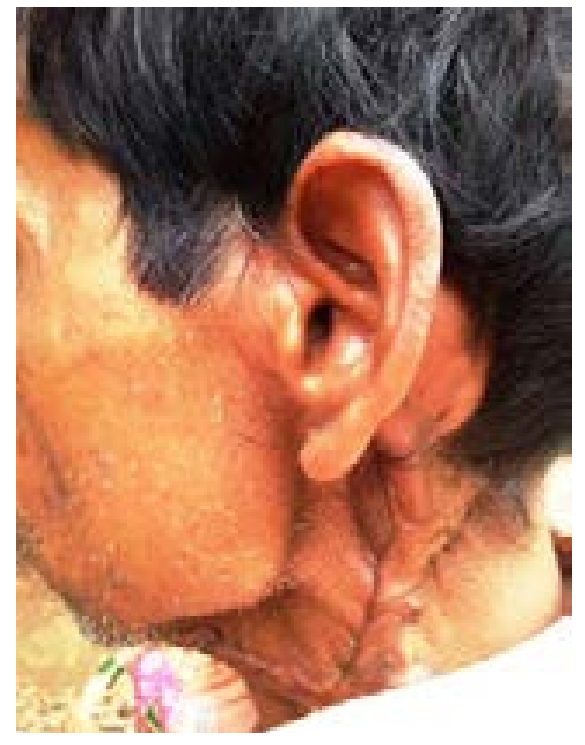

Fig 9: 24 months' postoperative view without any recurrence of the lesion

\section{Discussion}

CA-ex-PA known carcinoma in a mixed tumour or carcinoma ex mixed tumour typically found in the gland arising from pleomorphic adenoma.7 CA-ex-PA encompass about $6.2 \%$ of all mixed tumors, $3.6 \%$ of all tumors of salivary glands salivary tumors, $12 \%$ of all salivary malignancies.(4) CA-ex-PA which is an uncommon malignant tumor of salivary gland, has a prevalence rate of $5.6 \%$ cases/100,000 malignant tumors. The incidence rate of CA-ex-PA is $0.17 \%$ tumors $/ 1$ million persons. 8

Livolsi.V and Perzin.K in 1977 introduced the term non-invasive carcinoma ex pleomorphic adenoma and concept of malignant tumour arising in mixed tumour.9 This was supported by Spiro et al., but with the observation that histological indications demonstrate pre-existing salivary gland tumour. CA-ex-PA is a carcinomatous conversion inside a primary (de novo) or recurrent pleomorphic adenoma.

CA-ex-PA is mostly observed as a firm mass present in parotid gland. It has also been found to originate in sub-mandibular gland and at times in minor salivary glands in the region of hard and soft palate.10 Tumors at these sites are smaller in size compared to those arising from the major salivary glands. CA-ex-PA have also been identified in lacrimal glands, nasal cavities, trachea and breast.11-14 Literature on CA-ex-PA in different areas of head and neck region are added in a tabulated format indicating area of carcinoma, case reported with relevant information (Table 1). 
Table 1: Review of literature of CA-ex-PA

\begin{tabular}{|c|c|c|c|}
\hline Author/year & Area of Carcinoma & Case Reported & Reference \\
\hline Felix A et al 2002 & Parotid Gland & $\begin{array}{l}\text { Non-invasive Carcinoma ex Pleomorphic adenoma of malignant nature showing cervical lymph node } \\
\text { metastasis on the same side of the lesion }\end{array}$ & 15 \\
\hline Ethunandan et al 2006 & Parotid Gland & $\begin{array}{l}\text { Four cases of Carcinoma ex Pleomorphic adenoma showed atypical histologic features; out of which one } \\
\text { case exhibited benign vascular invasion and the other three exhibited malignant dysplastic features } \\
\text { suggestive of carcinoma without evidence of extra-capsular invasion. }\end{array}$ & 16 \\
\hline Tomoaki Mori et al 2010 & Parotid Gland & $\begin{array}{l}\text { Three cases of Non-invasive Carcinoma ex Pleomorphic adenoma showing features of an adenocarcinoma } \\
\text { not otherwise specified. }\end{array}$ & 17 \\
\hline Chooback et al 2017 & Parotid Gland & $\begin{array}{l}\text { A case of Carcinoma ex Pleomorphic adenoma of the left parotid gland. The histologic features were } \\
\text { supportive of malignant transformation showing predominantly sarcomatoid features. } \\
\text { The patient received multiple systemic therapy for locally recurrent lesion. }\end{array}$ & 2 \\
\hline Rossi et al 2014 & Parotid Gland & $\begin{array}{l}\text { Carcinoma ex pleomorphic adenoma metastasizing to the spleen. Both regional lymphatic and } \\
\text { distant haematogenous } \\
\text { spread were identified. }\end{array}$ & 18 \\
\hline Buva KB et al 2017 & Sub-mandibular Gland & $\begin{array}{l}\text { A case of non-invasive carcinoma ex pleomorphic adenoma. Benign part consisted of myxomatous area } \\
\text { with partial capsule and neoplastic cells showed invasion into capsule. }\end{array}$ & 19 \\
\hline Sharmila PS et al 2015 & Parotid Gland & $\begin{array}{l}\text { A case of carcinoma ex pleomorphic adenoma where malignant component exhibited mucoepidermoid } \\
\text { differentiation. }\end{array}$ & 20 \\
\hline Matsushima M et al 2012 & Sub-mandibular Gland & $\begin{array}{l}\text { The case report described a carcinoma ex pleomorphic adenoma of the sub-mandibular area exhibiting } \\
\text { renal metastasis. }\end{array}$ & 21 \\
\hline Mohan S et al 2015 & Parotid Gland & A rare case of non-invasive carcinoma ex pleomorphic adenoma exhibiting ossification in the tumour. & 22 \\
\hline Vahedi M et al 2016 & $\begin{array}{l}\text { Buccal Minor Salivary } \\
\text { Gland }\end{array}$ & $\begin{array}{l}\text { A rare case of carcinoma ex pleomorphic adenoma reported on buccal minor salivary gland. Author } \\
\text { suggested that in case of small and non-invasive carcinoma ex pleomorphic adenoma. Surgical excision is } \\
\text { the treatment of choice. }\end{array}$ & 23 \\
\hline Adagio E et al 2017 & Lacrimal Gland & $\begin{array}{l}\text { Carcinoma ex pleomorphic adenoma with epithelial and myoepithelial differentiation of left lacrimal gland } \\
\text { showing decreased vision, compressive optic neuropathy. The patient underwent radiation therapy and } \\
\text { remains free of clinical or radiographic disease } 24 \text { months following surgery }\end{array}$ & 24 \\
\hline Ariyoshi Y et al 2012 & Sublingual gland & $\begin{array}{l}\text { A case of carcinoma ex pleomorphic adenoma of a sublingual gland in Treatment carried out was excision } \\
\text { of the mass with the sublingual salivary gland in an en bloc fashion via an intraoral approach. } \\
\text { Histopathologic picture showed rupture of fibrous capsule and diffuse cell-rich sheets composed of } \\
\text { myoepithelial cells with round nuclei. Immunohistochemically, the cells that composed of cell rich sheets } \\
\text { were positive to smooth muscle actin. }\end{array}$ & 25 \\
\hline Sedassari BT et al 2014 & $\begin{array}{l}\text { Palatal minor salivary } \\
\text { gland }\end{array}$ & $\begin{array}{l}\text { A case of palatal minor salivary gland Carcinoma ex pleomorphic adenoma composed of invasive } \\
\text { micropapillary salivary duct carcinoma and adenoid cystic carcinoma components with multiple nodal } \\
\text { metastases. Neoplastic cells showed heterogeneous immunohistochemical profile with both luminal and } \\
\text { myoepithelial differentiation. The invasive micropapillary salivary duct carcinoma component } \\
\text { demonstrated overexpression of the oncoprotein human epidermal growth factor receptor-2. }\end{array}$ & 26 \\
\hline Chen $\mathrm{HH}$ et al 2010 & $\begin{array}{l}\text { Soft Palate minor } \\
\text { salivary gland }\end{array}$ & $\begin{array}{l}\text { A case of soft palatal mass progressing to left cheek numbness, proptosis. Biopsy of soft palatal tumor } \\
\text { revealed pleomorphic adenoma. Magnetic resonance imaging showed a tumor involving left maxilla } \\
\text { extending from pterygopalatine fossa, inferior orbital fissure to cavernous sinus. Excision of tumor } \\
\text { revealed Carcinoma ex pleomorphic adenoma with adjuvant concomitant chemo-radiation therapy. }\end{array}$ & 27 \\
\hline Liao PW et al 2016 & $\begin{array}{l}\text { Minor salivary gland of } \\
\text { nasal cavity }\end{array}$ & $\begin{array}{l}\text { An unusual case of pedunculated intranasal Carcinoma ex pleomorphic adenoma wherein a wide } \\
\text { endoscopic excision was carried out with no recurrence. }\end{array}$ & 28 \\
\hline Sakamoto Y et al 2017 & $\begin{array}{l}\text { Minor salivary gland of } \\
\text { the tongue }\end{array}$ & $\begin{array}{l}\text { A case of carcinoma ex pleomorphic adenoma of right dorsum of tongue with a history of breast } \\
\text { carcinoma. Macroscopic examination revealed an oval tumor with a smooth mucosal surface of } 10 \mathrm{~mm} \text { in } \\
\text { diameter in the right dorsum of tongue. Histologic examination revealed carcinoma ex pleomorphic } \\
\text { adenoma. Treatment undertaken was partial glossectomy. }\end{array}$ & 29 \\
\hline Onur Ismı et al 2015 & $\begin{array}{l}\text { Sub-mandibular region } \\
\text { apart from sub- } \\
\text { mandibular gland }\end{array}$ & $\begin{array}{l}\text { A rare case of carcinoma ex pleomorphic adenoma of neck. Histopathological examination revealed an } \\
\text { intracapsular malign tumor composed of both myoepithelial and epithelial components in a lobular pattern } \\
\text { close to parotid gland. Treatment rendered was total excision of the mass. }\end{array}$ & 30 \\
\hline Goyal P et al 2016 & $\begin{array}{l}\text { Minor salivary gland of } \\
\text { buccal mucosa }\end{array}$ & $\begin{array}{l}\text { This case report describes a carcinoma ex pleomorphic adenoma of the buccal mucosa which was } \\
\text { dissected and excised. It's a diagnostic challenge at such locations. }\end{array}$ & 31 \\
\hline Mitate E. et al 2013 & $\begin{array}{l}\text { Minor salivary gland of } \\
\text { upper lip }\end{array}$ & $\begin{array}{l}\text { A rare case of carcinoma ex pleomorphic adenoma located on upper lip Tumor was removed and } \\
\text { histologic revealed well-demarcated tumor tissues showing typical histologic features of pleomorphic } \\
\text { adenoma and mitotic figures in central area of tumor tissue suggestive of squamous cell carcinoma. }\end{array}$ & 32 \\
\hline Sreedharan S et al 2012 & Maxillary sinus & $\begin{array}{l}\text { A rare case of carcinoma ex pleomorphic adenoma in maxillary sinus with histopathological examination } \\
\text { and management. }\end{array}$ & 33 \\
\hline
\end{tabular}

CA-ex-PA has more predilection for females compared to males and is frequently seen during sixth to seventh decade of life. ${ }^{34,35}$ Based on extent of carcinomatous component outside the fibrous capsule, CA-ex-PA can be sub-classified as i) non-invasive ii) minimally invasive $(<1.5 \mathrm{~mm}$ penetration of malignant element into extracapsular tissue) and, iii) invasive (greater than $1.5 \mathrm{~mm}$ invasion from tumor capsule into to neighbouring tissues). ${ }^{36,37}$
Invasive type has non-defined infiltrative margins. There is very high nuclear pleomorphism with prominent nucleoli. There is adjacent perivascular and perineural infiltration with haemorrhagic and necrotic foci. Where as in Non-invasive type has well-defined borders with very little pleomorphic nuclei. Small quantity of myxoid area is seen. Mix of Cellular and acellular areas are observed in low foci. As per the histological results, our case is an 
example of invasive type. As per WHO classification published in 2005 for malignant changes of pleomorphic adenoma, CA-ex-PA is the one which is most frequently encountered in comparison to metastasizing PA and carcinosarcoma. ${ }^{27}$ In our case, four important clues to arrive at a diagnosis were 1) location of swelling in the parotid region, 2) Fine needle aspiration cytology showing mixture of benign and malignant cells 3) Fluorodeoxyglucose (FDG) positron emission tomography showed an increased uptake in left parotid region, neck and 4) Ultra-sonography of neck for mapping of lymph nodes showing metastasis. On this basis, we arrived at the diagnosis of Carcinoma ex pleomorphic adenoma. Adjuvant pre-treatment fine needle aspiration cytology, fluorodeoxyglucose (FDG) positron emission tomography and ultrasonography aid in making preliminary diagnosis and extent of metastasis. Pre-operative diagnosis of tumor of parotid gland is established on basis of history, clinical findings, FNA findings, histologipicture. FNAC is frequently used preoperatively for diagnosis of CA-ex-PA. The sensitivity is still low mainly associated with error in sampling ${ }^{4}$, cytomorphological variability and less experience. Lesions salivary glands with suspected carcinoma, it is important to have aspiration from multiple sites. CAex-PA can be misdiagnosed as some other malignant salivary gland tumor or mistaken with PA. Abundant atypical cells, coarsely clumped chromatin with prominent nucleoli and necrosis are key features in distinguishing PA from malignant tumors including CA-ex-PA.

In majority of cases of PA, most common malignancy observed is adenocarcinoma NOS (not otherwise specified). The other unusual malignancies which can be seen in relation to PA are that can arise in setting of PA are myoepithelial carcinoma, adenosquamous carcinoma, undifferentiated carcinoma ,adenoid cystic carcinoma and sarcomatoid carcinoma. ${ }^{35,38}$ In our case, it was adenocarcinoma NOS developing in setting of PA.

Treatment often involves a surgical procedure(parotidectomy), which may be followed by radiotherapy. Superficial parotidectomy is done in cases of minimally invasive CAex-PA whereas complete or radical parotidectomy is done for frankly invasive CA-ex-PA. A related neck dissection is also undertaken if cervical lymph nodes presents with evidence of metastases. Neck dissection may be functional, modified, or radical as per the indications. The surgical technique to eliminate the neoplasm could be followed by reconstructive surgery. A soft tissue reconstruction like radial free flap or a cervical rotation flap is accomplished in various cases for repair of the defect. In our case the reconstruction was facilitated by cervico-deltopectoral flap. Patients can be given with options of combination of chemotherapy and radiotherapy. Post-operative radiotherapy is normally used in cases of high grade disease or questionable resection adequacy, and for invasion of perineural tissues and lymph nodes. ${ }^{39}$ in this case, both radiotherapy and chemotherapy with a boost of radiation at level IIB was given as per the treatment plan. Multiple factors like type of invasion, lymph node and local or distant metastasis, tumor grade and size and total removal of tumor does dictate prognosis of CA-ex-PA. ${ }^{34,36}$ Survival rates of these patients may be increased by prefect diagnosis of CA-ex-PA along with complete surgical and radiological treatment of these patients. ${ }^{36}$

Recent molecular investigations of CA-ex-PA has provided with new insights on its carcinogenesis. It is seen that there is a progressive loss of heterozygosity $(\mathrm{LOH})$ at chromosomal arms 8q, 12q, and 17p. ${ }^{40}$ Role of p53 gene has been suspected in pathogenesis of CA-ex-PA. Righi et al first reported with point mutation of p53 in CA-exPA. ${ }^{41}$ Patel et al found better immunohistochemical staining for p16 proteins and cyclin D1 with malignant components of CA-ex-PA compared to normal stromal and epithelial components. ${ }^{42}$ Also with progression of CAex-PA, expression of p21 gene may increase, linking to its role in progression of disease. ${ }^{43}$ Levels of COX-2 are sufficiently lower in PA compared to CA-ex-PA suggestive of increased expression of COX-2 could be an relevant as an early stage event in the pathogenesis of the this disease. ${ }^{44}$ Epidermal growth factor receptor (EGFR) ${ }^{44}$, HGF-A (scatter factor) and c-Met (a proto-oncogene) (45), Transforming growth factor alpha (TGF $\alpha)^{44}$, Fibroblast growth factors (FGF)-2 45 have been investigated to have a role in progression and invasion of CA-ex-PA. There was increased expression of E-cadherin expression in cases of CA-ex-PA with comparatively less reactivity in comparison to benign tumours. ${ }^{46}$ Thus, along with clinical, histological findings, these specific candidate genes which have been associated with the development and progression of CA-ex-PA should be considered as a vital diagnostic aid for confirmation of lesion.

\section{Conclusion}

Ca ex PA is an uncommon aggressive malignancy. Quite often it is associated with regional metastasis which invariably leads to mortality. It also poses a difficulty in diagnosis, as the mixed tumour component is usually minute 
and is easily overlooked, and the malignant component may be difficult to classify. ${ }^{1}$ Preoperative diagnosis of salivary gland tumours is quite challenging because of the overlap in histopathological characteristics. Due to the similarity of clinical symptoms of $\mathrm{Ca}$ ex PA and benign pleomorphic adenoma, it is vital that clinicians maintain a high degree of clinical vigilance, considering the oddity of this malignancy and performs postoperative immunohistochemistry and fluorescence in situ hybridization for HMGA-2 gene to confirm the diagnosis. In conclusion, early and prompt diagnosis followed by aggressive surgical intervention of patients with Carcinoma ex pleomorphic adenoma can enhance their survival rates.

\section{Conflict of interest}

None declared.

\section{References}

1. Keerthi R, Raut RP, Vaibhav N, Ghosh A. Carcinoma ex pleomorphic adenoma: Diagnostic dilemma and treatment protocol. Indian J Dent [Internet]. Wolters Kluwer -- Medknow Publications; 2014 Jul [cited 2018 Jun 19];5(3):157-60. Available from: http://www.ncbi.nlm. nih.gov/pubmed/25565746

2. Chooback N, Shen Y, Jones M, Kasaian K, Martin $\mathrm{M}, \mathrm{Ng} \mathrm{T}$, et al. Carcinoma ex pleomorphic adenoma: case report and options for systemic therapy. Curr Oncol [Internet]. Multimed Inc.; 2017 Jun [cited 2018 Jun 21];24(3):e251-4. Available from: http://www.ncbi.nlm. nih.gov/pubmed/28680294

3. Di Palma S. Carcinoma ex pleomorphic adenoma, with particular emphasis on early lesions. Head Neck Pathol [Internet]. Springer; 2013 Jul [cited 2018 Jun 21];7 Suppl 1(Suppl 1):S68-76. Available from: http://www.ncbi.nlm. nih.gov/pubmed/23821206

4. Antony J, Gopalan V, Smith RA, Lam AKY. Carcinoma ex Pleomorphic Adenoma: A Comprehensive Review of Clinical, Pathological and Molecular Data. Head Neck Pathol [Internet]. 2012 Mar 9 [cited 2018 Jun 14];6(1):1-9. Available from: http://www.ncbi.nlm.nih. gov/pubmed/21744105

5. Zbären P, Schüpbach J, Nuyens M, Stauffer E, Greiner R, Häusler R. Carcinoma of the parotid gland. Am J Surg [Internet]. 2003 Jul [cited 2018 Jun 21];186(1):5762. Available from: http://www.ncbi.nlm.nih.gov/ pubmed/12842751

6. Wakasaki T, Kubota M, Nakashima Y, Tomonobe E, Mihara T, Fukushima J. Invasive myoepithelial carcino- ma ex pleomorphic adenoma of the major salivary gland: two case reports. BMC Cancer [nternet]. BioMed Central; 2016 Dec 28 [cited 2018 Jun 21];16(1):827. Available from: http://bmccancer.biomedcentral.com/articles/10.1186/ s12885-016-2871-3

7. Dardick I. Color atlas/text of salivary gland tumor pathology. $274 \mathrm{p}$.

8. Gnepp DR. Malignant mixed tumors of the salivary glands: a review. Pathol Annu [Internet]. 1993 [cited 2018 Jun 14];28 Pt 1:279-328. Available from: http://www. ncbi.nlm.nih.gov/pubmed/8380049

9. LiVolsi VA, Perzin KH. Malignant mixed tumors arising in salivary glands. I. Carcinomas arising in benign mixed tumors: a clinicopathologic study. Cancer [nternet]. 1977 May [cited 2018 Jun 14];39(5):2209-30. Available from: http://www.ncbi.nlm.nih.gov/pubmed/192443 10. Damm DD, Fantasia JE. Large palatal mass. Carcinoma ex-pleomorphic adenoma. Gen Dent [nternet]. [cited 2018 Jun 14];49(6):574, 658. Available from: http://www. ncbi.nlm.nih.gov/pubmed/12024743

11. Baredes S, Ludwin DB, Troublefield YL, Langer PD, Mirani N. Adenocarcinoma Ex-Pleomorphic Adenoma of the Lacrimal Sac and Nasolacrimal Duct: A Case Report. Laryngoscope [Internet]. 2003 Jun [cited 2018 Jun 14];113(6):940-2. Available from: http://www.ncbi.nlm. nih.gov/pubmed/12782801

12. Ding CSL, Yap WM, Teo CHY, Giron D, Chuah KL. Tracheal carcinoma ex pleomorphic adenoma: a rare tumour with potential problems in diagnosis. Histopathology [Internet]. 2007 Dec [cited 2018 Jun 14];51(6):86871. Available from: http://www.ncbi.nlm.nih.gov/ pubmed/17916072

13. Cho KJ, el-Naggar AK, Mahanupab P, Luna MA, Batsakis JG. Carcinoma ex-pleomorphic adenoma of the nasal cavity: a report of two cases. J Laryngol Otol [nternet]. 1995 Jul [cited 2018 Jun 14];109(7):677-9. Available from: http://www.ncbi.nlm.nih.gov/pubmed/7561483

14. Hayes MM, Lesack D, Girardet C, Del Vecchio M, Eusebi V. Carcinoma ex-pleomorphic adenoma of the breast. Report of three cases suggesting a relationship to metaplastic carcinoma of matrix-producing type. Virchows Arch [Internet]. 2005 Feb 4 [cited 2018 Jun 14];446(2):142-9. Available from: http://www.ncbi.nlm. nih.gov/pubmed/15583933

15. Felix A, Rosa-Santos J, Mendonça ME, Torrinha F, Soares J. Intracapsular carcinoma ex pleomorphic adenoma. Report of a case with unusual metastatic behaviour. Oral Oncol [nternet]. 2002 Jan [cited 2018 Jun 
24];38(1):107-10. Available from: http://www.ncbi.nlm. nih.gov/pubmed/11755829

16. Ethunandan M, Witton R, Hoffman G, Spedding A, Brennan PA. Atypical features in pleomorphic adenoma-a clinicopathologic study and implications for management. Int J Oral Maxillofac Surg [Internet]. 2006 Jul [cited 2018 Jun 24];35(7):608-12. Available from: http:/ / www.ncbi.nlm.nih.gov/pubmed/16540285

17. MORI T, KUNIMURA T, SAITO K, DATE H, ARIMA S, MATSUO K, et al. Three Cases of Noninvasive Carcinoma ex Pleomorphic Adenoma of the Parotid Gland and a Literature Survey Focusing on their Clinicopathologic Features. Showa Univ J Med Sci [Internet]. The Showa University Society; 2010 [cited 2018 Jun 24];22(2):127-34. Available from: http://jlc.jst.go.jp/JST. JSTAGE/sujms $/ 22.127$ ?lang $=$ en\&from $=$ CrossRef\&type $=$ abstract

18. Rossi L, Giordani E, Fontana A, Di Cristofano C, Cavallaro G, Bagni O, et al. An unusual case of spleen metastasis from carcinoma ex pleomorphic adenoma of the parotid gland. World J Surg Oncol [Internet]. BioMed Central; 2014 Jan 23 [cited 2018 Jun 24];12:18. Available from: http://www.ncbi.nlm.nih.gov/pubmed/24456816 19. Buva KB, Deshmukh AA, Deshmukh AA. A Case Report of Rare Carcinoma Ex Pleomorphic Adenoma of Sub-mandibular Gland and its Detailed Description. J Clin DIAGNOSTIC Res [Internet]. 2017 May [cited 2018 Jun 24];11(5):ZD15-ZD17. Available from: http://www. ncbi.nlm.nih.gov/pubmed/28658924

20. Sharmila P, Shashikala K, Harish K, Jeychandran P. An Unusual Case of Carcinoma Ex-pleomorphic Adenoma of the Parotid Gland: A Comprehensive Clinicopathological Review. Sahajananda H, editor. J Med Sci [nternet]. 2015 [cited 2018 Jun 24];1:44-6. Available from: http:// www.jaypeejournals.com/eJournals/ShowText.aspx?ID $=8553 \&$ Type $=$ FREE $\&$ TYP $=$ TOP $\& I N=\sim /$ eJour nals $/$ images $/$ JPLOGO.gif\&IID $=660 \&$ isPDF $=$ YES

21. Matsushima M, Ohara R, Ishida M, Kanao K, Shimokawa R, Nakajima Y. Carcinoma ex pleomorphic adenoma of the sub-mandibular gland with renal metastases composed exclusively of metastasizing pleomorphic adenoma. Int Cancer Conf J [Internet]. Springer Japan; 2012 Apr 30 [cited 2018 Jun 24];1(2):116-20. Available from:http://link.springer.com/10.1007/s13691-0120024-3

22. Mohan S, Puram S V, Yarlagadda B, Nosé V, Deschler DG. Ossifying Parotid Carcinoma ex Pleomorphic Adenoma. Case Rep Otolaryngol [Internet]. Hindawi; 2015
May 17 [cited 2018 Jun 24];2015:395358. Available from: http://www.ncbi.nlm.nih.gov/pubmed/26075129

23. Vahedi M, Jamalpour MR, Hashemi A, Ronasi N, Abdolkarimpour Z. Carcinoma ex pleomorphic adenoma in the buccal minor salivary gland: a rare case report. $S_{c h}$ Acad J Biosci Sch Acad J Biosci [Internet]. 2016 [cited 2018 Jun 24];4(8). Available from: www.saspublisher.com 24. Avdagic E, Farber N, Katabi N, Shinder R. Carcinoma Ex Pleomorphic Adenoma of the Lacrimal Gland with Epithelial-Myoepithelial Carcinoma Histologic Type. Ophthal Plast Reconstr Surg [Internet]. 2017 [cited 2018 Jun 24];33(3S Suppl 1):S136-8. Available from: http://www. ncbi.nlm.nih.gov/pubmed/26934566

25. Ariyoshi Y, Shimahara M, Konda T, Tsuji M. Carcinoma ex pleomorphic adenoma of the sublingual gland: a case report. Int J Oral Sci [nternet]. Nature Publishing Group; 2012 Apr 12 [cited 2018 Jun 24];4(1):50-3. Available from: http://www.nature.com/articles/ijos20123 26. Sedassari BT, da Silva Lascane NA, Tobouti PL, Pigatti FM, Franco MIF, de Sousa SCOM. Carcinoma Ex Pleomorphic Adenoma of the Palate Composed of Invasive Micropapillary Salivary Duct Carcinoma and Adenoid Cystic Carcinoma Components. Medicine (Baltimore) [Internet]. 2014 Dec [cited 2018 Jun 24];93(27):e146. Available from: http://www.ncbi.nlm. nih.gov/pubmed/25501054

27. Chen H-H, Lee L-Y, Chin S-C, Chen I-H, Liao C-T, Huang S-F. Carcinoma ex pleomorphic adenoma of soft palate with cavernous sinus invasion. World J Surg Oncol [Internet]. BioMed Central; 2010 Mar 30 [cited 2018 Jun 19];8:24. Available from: http://www.ncbi.nlm.nih.gov/ pubmed $/ 20353573$

28. Liao P-W, Chen Y-L, Chen J-W. Pedunculated carcinoma ex pleomorphic adenoma of the nasal cavity. Medicine (Baltimore) [Internet]. 2016 Sep [cited 2018 Jun 25];95(39):e5004. Available from: http://www.ncbi.nlm. nih.gov/pubmed/27684860

29. Sakamoto Y, Fujita S, Adachi M, Sakamoto H, Naruse T, Yanamoto S, et al. Carcinoma Ex Pleomorphic Adenoma of the Tongue. J Craniofac Surg [Internet]. 2017 Mar [cited 2018 Jun 25];28(2):e182-5. Available from: http:/ / www.ncbi.nlm.nih.gov/pubmed/27755404

30. Ismı O, Vayısoğlu Y, Arpaci RB, Eti C, Pütürgeli T, Gorur K, et al. Carcinoma ex pleomorphic adenoma originating from ectopic salivary gland in the neck region: case report. Gland Surg [Internet]. 2015 Dec [cited 2018 Jun 25];4(6):567-71. Available from: http://www.ncbi. nlm.nih.gov/pubmed/26645012 
31. Goyal P, Sehgal S, Ghosh S, Agrawal D, Singh S. Rare Carcinoma Ex-pleomorphic Adenoma of Buccal Mucosa: Case Report and Review of Literature. Rare Tumors [Internet]. SAGE Publications; 2016 Mar 21 [cited 2018 Jun 25];8(1):6138. Available from: http://www.ncbi.nlm. nih.gov/pubmed/27134712

32. Mitate E, Kawano S, Kiyoshima T, Kawazu T, Chikui T, Goto Y, et al. Carcinoma ex pleomorphic adenoma of the upper lip: a case of an unusual malignant component of squamous cell carcinoma. World J Surg Oncol [Internet]. BioMed Central; 2013 Sep 17 [cited 2018 Jun 25];11:234. Available from: http://www.ncbi.nlm.nih. gov/pubmed/24044722

33. Sreedharan S, Prasad KC, Hegde MC, Sahoo K, Alva A. Carcinoma ex pleomorphic adenoma of the maxillary sinus: a case report. Ear Nose Throat J [nternet]. 2012 Dec [cited 2018 Jun 25];91(12):E1-3. Available from: http:// www.ncbi.nlm.nih.gov/pubmed/23288822

34. Gnepp DR. Diagnostic surgical pathology of the head and neck. Saunders/Elsevier, 2009. 1205 p.

35. Auclair P. Tumors of the salivary glands. [s.n.]; 2008. 36. Barnes L, UniversitätsSpital Zürich. Departement Pathologie., International Academy of Pathology., World Health Organization., International Agency for Research on Cancer. Pathology and genetics of head and neck tumours. IARC Press; 2005. 430 p.

37. Altemani A, Martins MT, Freitas L, Soares F, Araujo NS, Araujo VC. Carcinoma ex pleomorphic adenoma (CXPA): immunoprofile of the cells involved in carcinomatous progression. Histopathology [Internet]. 2005 Jun [cited 2018 Jun 14];46(6):635-41. Available from: http:/ / www.ncbi.nlm.nih.gov/pubmed/15910594

38. Mariano F V, Noronha ALF, Gondak RO, Altemani AM de AM, de Almeida OP, Kowalski LP. Carcinoma ex pleomorphic adenoma in a Brazilian population: clinico-pathological analysis of 38 cases. Int J Oral Maxillofac Surg [Internet]. Elsevier; 2013 Jun 1 [cited 2018 Jun 19];42(6):685-92. Available from: http://www.ncbi.nlm. nih.gov/pubmed/23561262

39. Lüers J-C, Wittekindt C, Streppel M, Guntinas-Lichius O. Carcinoma ex pleomorphic adenoma of the parotid gland. Study and implications for diagnostics and therapy. Acta Oncol (Madr) [Internet]. 2009 Jan 8 [cited 2018 Jun
19];48(1):132-6. Available from: http://www.ncbi.nlm. nih.gov/pubmed/18607845

40. El-Naggar AK, Callender D, Coombes MM, Hurr K, Luna MA, Batsakis JG. Molecular genetic alterations in carcinoma ex-pleomorphic adenoma: a putative progression model? Genes Chromosomes Cancer [nternet]. 2000 Feb [cited 2018 Jun 19];27(2):162-8. Available from: http:/ / www.ncbi.nlm.nih.gov/pubmed/10612804

41. Righi PD, Li YQ, Deutsch M, McDonald JS, Wilson KM, Bejarano P, et al. The role of the p53 gene in the malignant transformation of pleomorphic adenomas of the parotid gland. Anticancer Res [Internet]. [cited 2018 Jun 19];14(5B):2253-7. Available from: http://www.ncbi. nlm.nih.gov/pubmed/7840532

42. Patel RS, Rose B, Bawdon H, Hong A, Lee CS, Fredericks S, et al. Cyclin D1 and p16 expression in pleomorphic adenoma and carcinoma ex pleomorphic adenoma of the parotid gland. Histopathology [Internet]. 2007 Nov [cited 2018 Jun 19];51(5):691-6. Available from: http:// www.ncbi.nlm.nih.gov/pubmed/17927591

43. Tarakji B, Nassani MZ, Sloan P. Immunohistochemical expression of estrogens and progesterone receptors in carcinoma ex pleomorphic adenoma-undifferentiated and adenocarcinoma types. Med Oral Patol Oral Cir Bucal [Internet]. 2010 May 1 [cited 2018 Jun 19];15(3):e4326. Available from: http://www.ncbi.nlm.nih.gov/ pubmed $/ 20038908$

44. Katori H, Nozawa A, Tsukuda M. Increased expression of cyclooxygenase- 2 and $\mathrm{Ki}-67$ are associated with malignant transformation of pleomorphic adenoma. Auris Nasus Larynx [Internet]. 2007 Mar [cited 2018 Jun 19];34(1):79-84. Available from: http://www.ncbi.nlm. nih.gov/pubmed/17049779

45. Furuse C, Miguita L, Rosa ACG, Soares AB, Martinez EF, Altemani A, et al. Study of growth factors and receptors in carcinoma ex pleomorphic adenoma. J Oral Pathol Med [Internet]. Wiley/Blackwell (10.1111); 2010 Feb [cited 2018 Jun 19];39(7):540-7. Available from: http://doi. wiley.com/10.1111/j.1600-0714.2009.00858.x

46. Prabhu S, Kaveri H, Rekha K. Benign ; malignant salivary gland tumors: comparison of immunohistochemical expression of e-cadherin. Oral Oncol [Internet]. 2009 Jul [cited 2018 Jun 19];45(7):594-9. Available from: http:/ / www.ncbi.nlm.nih.gov/pubmed/18955011 